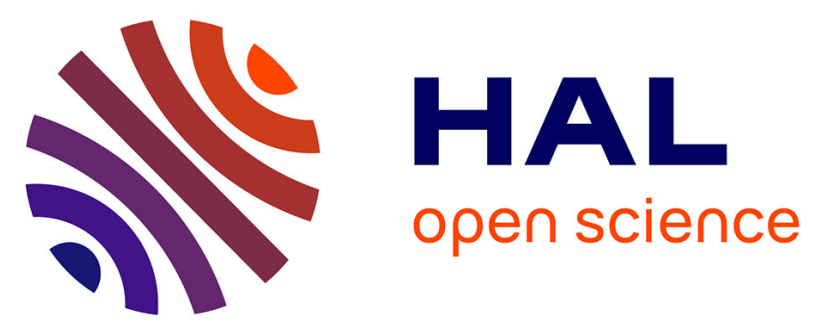

\title{
A novel pathogenic variant in DYNC1H1 causes various upper and lower motor neuron anomalies
}

Louis M Viollet, Kathryn J Swoboda, Rong Mao, Hunter Best, Youna Ha, Annick Toutain, Lucie Guyant-Marechal, Cecile Laroche-Raynaud, Karima Ghorab, Marie Anne Barthez, et al.

\section{To cite this version:}

Louis M Viollet, Kathryn J Swoboda, Rong Mao, Hunter Best, Youna Ha, et al.. A novel pathogenic variant in DYNC1H1 causes various upper and lower motor neuron anomalies. European Journal of Medical Genetics, 2020, 63 (12), pp.104063. 10.1016/j.ejmg.2020.104063 . hal-03182670

\section{HAL Id: hal-03182670 \\ https://hal.sorbonne-universite.fr/hal-03182670}

Submitted on 26 Mar 2021

HAL is a multi-disciplinary open access archive for the deposit and dissemination of scientific research documents, whether they are published or not. The documents may come from teaching and research institutions in France or abroad, or from public or private research centers.
L'archive ouverte pluridisciplinaire HAL, est destinée au dépôt et à la diffusion de documents scientifiques de niveau recherche, publiés ou non, émanant des établissements d'enseignement et de recherche français ou étrangers, des laboratoires publics ou privés. 


\title{
A novel single dominant DYNC1H1 pathogenic variant causes
}

\section{various upper and lower motor neuron anomalies}

\author{
Authors: Yue Si, MD, PhD; Kathryn J Swoboda, MD; Rong Mao, MD; Hunter Best, PhD; Youna \\ $\mathrm{Ha}$, BSc; Annick Toutain, MD, PhD; Lucie Guyant-Marechal, MD; Cecile Laroche-Raynaud, MD; \\ Karima Ghorab, MD; Marie Anne Barthez, MD; Jean Michel Pedespan, MD; Xavier \\ Hernandorena, MD; Anne-Sophie Lia, PhD; Jean-Francois Deleuze, PhD; Cecile Masson, MSc; \\ Isabelle Nelson, PhD; Juliette Nectoux, PharmD, PhD and Louis M Viollet, MD, PhD \\ Yue Si, ARUP Institute for Clinical and Experimental Pathology, ARUP laboratories and Department of \\ Pathology, University of Utah School of Medicine, Salt Lake City, UT; GeneDx, Whole Exome Sequencing \\ Program, Gaithersburg, MD \\ Kathryn Swoboda, Pediatric Motor Disorders Research Program, University of Utah School of Medicine, \\ Salt Lake City, UT and Department of Neurology, Massachusetts General Hospital, Boston, MA \\ Rong Mao, ARUP Institute for Clinical and Experimental Pathology, ARUP laboratories and Departments \\ of Pathology and Medical Genetics/Pediatrics, University of Utah School of Medicine, Salt Lake City, UT \\ Hunter Best, ARUP Institute for Clinical and Experimental Pathology, ARUP laboratories and \\ Departments of Pathology and Medical Genetics/Pediatrics, University of Utah School of Medicine, Salt \\ Lake City, UT \\ Youna Ha, ARUP Institute for Clinical and Experimental Pathology, ARUP laboratories, Salt Lake City, UT \\ Annick Toutain, Génétique clinique, Hopital Bretonneau, Tours, France \\ Lucie Guyant-Marechal, Genetique Clinique, Hopital Charles Nicolle, Rouen, France \\ Cecile Laroche-Raynaud, Neuropediatrie, Hopital Mere et Enfant, Limoges, France \\ Karima Ghorab, Neurologie, Hopital Dupuytren, Limoges, France \\ Marie Anne Barthez, Neuropediatrie, CHU de Tours, Hopital Clocheville, France \\ Jean Michel Pedespan, Neuropediatrie, Hopital Pellegrin, Bordeaux, France \\ Xavier Hernandorena, Pediatrie, Centre Hospitalier de la Cote Basque, Bayonne, France \\ Anne-Sophie Lia, Biochimie et Genetique Moleculaire, Hopital Dupuytren, Limoges, France \\ Jean-Francois Deleuze, CEA-CNG, Evry, France \\ Cecile Masson, Institut Imagine, Hopital Necker Enfants Malades, Paris, France \\ Isabelle Nelson, Institut de Myologie, Hopital Pitie Salpetriere, France \\ Juliette Nectoux, Biochimie et Genetique Moleculaire, Hopital Cochin, Paris, France. \\ Louis Viollet, Pediatric Motor Disorders Research Program and Department of Medical \\ Genetics/Pediatrics, University of Utah School of Medicine, Salt Lake City, UT
}

Title character count: 86

Number of references: 27

Number of tables: 2

Number of figures: 2

Word count abstract: 191 
Supplemental Data: 0

Corresponding Author:

Yue $\mathrm{Si}$

GeneDx

Whole Exome Sequencing Program

207 Perry Parkway

Gaithersburg, MD 20877

ysi@genedx.com

Louis M VIOLLET

Division of Medical Genetics/Department of Pediatrics

The University of Utah

295 Chipeta Way

Salt Lake City, Utah 84108

Phone: (801) 213-3599

Fax: (801) 585-7252

louis.viollet@hsc.utah.edu

ysi@genedx.com

Kathryn J Swoboda KSWOBODA@mgh.harvard.edu

Rong Mao rong.mao@aruplab.com

Hunter Best hunter.best@aruplab.com

Youna Ha youna.ha@aruplab.com

Annick Toutain annick.toutain@univ-tours.fr

Lucie Guyant-Marechal Lucie.Guyant@chu-rouen.fr

Cecile Laroche-Raynaud cecile.laroche@chu-limoges.fr

Karima Ghorab karima.ghorab@chu-limoges.fr

Marie Anne Barthez ma.barthez@chu-tours.fr

Jean Michel Pedespan jean-michel.pedespan@chu-bordeaux.fr

Xavier Hernandorena xhernandorena001@ch-cotebasque.fr

Anne-Sophie Lia asliabaldini@unilim.fr

Jean-Francois Deleuze isabelle.laudier@cea.fr

Cecile Masson cecile.masson@gmail.com

Isabelle Nelson isabelle.nelson@upmc.fr

Juliette Nectoux juliette.nectoux@aphp.fr

Louis M Viollet louis.viollet@hsc.utah.edu

Search Terms: Spinal Muscular Atrophy, Spastic Paraplegia, Motor neuropathy, Motor neuron disease, Dynein motor complex, Exome, Next Generation Sequencing

Author Contributions:

Yue $\mathrm{Si}$, design and conceptualization of the laboratory investigation, acquisition, analysis and interpretation of data, drafting/revising manuscript 
Kathryn J. Swoboda, analysis or interpretation of data, revising manuscript Rong Mao, analysis or interpretation of data, drafting/revising manuscript Hunter Best, acquisition of data, analysis or interpretation of data Youna $\mathrm{Ha}$, acquisition of data, analysis or interpretation of data Annick Toutain, acquisition of data, revising manuscript Lucie Guyant-Marechal, acquisition of data, revising manuscript for content Cecile Laroche-Raynaud, acquisition of data, revising manuscript Karima Ghorab, acquisition of data, revising manuscript Marie Anne Barthez, acquisition of data, revising manuscript Jean Michel Pedespan, acquisition of data, revising manuscript Xavier Hernandorena, acquisition of data, revising manuscript Anne-Sophie Lia, analysis or interpretation of data Jean-Francois Deleuze, analysis or interpretation of data Cecile Masson, analysis or interpretation of data Isabelle Nelson, analysis or interpretation of data Juliette Nectoux, analysis or interpretation of data, drafting/revising manuscript Louis Viollet, design and conceptualization the clinical investigation, acquisition of data, analysis or interpretation of data, drafting/revising manuscript

\author{
Author Disclosures: none \\ Study funded by: \\ Genetique ACTIONS \\ Association Francaise contre les Myopathies \\ University of Utah, Department of Pathology \\ Universite Paris Descartes, Department of Human Genetics, Hopital Necker Enfants Malades
}




\begin{abstract}
Objective: To perform genotype-phenotype, clinical and molecular analysis in a large 3generation family with autosomal dominant congenital spinal muscular atrophy.

Methods: Using a combined genetic approach including whole genome scanning, next generation sequencing-based multigene panel and targeted variant Sanger sequencing, we studied the proband and multiple affected individuals of this family who presented with bilateral proximal lower limb muscle weakness and atrophy.

Results: we identified a novel heterozygous variant, c.1826T>C; p.lle609Thr, in the DYNC1H1 gene localized within the common haplotype in the $14 q 32.31$ chromosomal region cosegregated with disease in this large family. Within the family, affected individuals were found to have a wide array of clinical variability. Although some individuals presented the typical lower motor neuron phenotype (SMA-LED) with areflexia and denervation, others presented with muscle weakness and atrophy, hyperreflexia and absence of denervation suggesting a predominant upper motor neuron disease. In addition, some affected individuals presented with an intermediate phenotype characterized by hyperreflexia and denervation, expressing a combination of lower and upper motor neuron defects.

Conclusion: Our study demonstrates the wide clinical variability associated with a single DYNC1H1 mutation and this mutation demonstrated a high penetrance within this large family.
\end{abstract}

Key words:

DYNC1H1, Spinal muscular atrophies, Exome

\title{
Introduction
}

Motor neuron disorders from a large spectrum of inherited diseases including spinal muscular atrophies (SMA), familial amyotrophic lateral scleroses (FALS), hereditary spastic paraplegias (HSP) and overlapping phenotypes. Each of these diseases are genetically heterogeneous and are commonly classified by their mode of inheritance, the spatial distribution of muscle weakness, the age at onset, the severity and the occasional presence of additional clinical features. ${ }^{1,2}$ Autosomal dominant Spinal Muscular Atrophy with Lower limb predominance (SMA-LED; OMIM\# $\underline{158600}$ ) is a clinically well characterized type of SMA, with autosomal dominant inheritance, 
YUE Si - 5

congenital or early childhood onset, lower limb predominant weakness and slow or absent progression. ${ }^{3-7}$ Two genes have been associated with SMA-LED: DYNC1H1 (Dynein Heavy Chain 1), coding for a major component of the Dynein-Dynactin motor complex and BICD2 (Bicaudal D2) a molecular partner of DYNC1H1. ${ }^{8-20}$ Mutations in both of these genes cause lower and upper motor neuron diseases. Some DYNC1H1 mutations cause SMA-LED, others cause axonal Charcot Marie Tooth disease (CMT 20 ; OMIM\# $\underline{614228}$ ) and some mutations cause hereditary spastic paraplegia (SPG3 ; OMIM\# 182600) $)^{9,14,16,21}$. Here we studied a large 3generation family with 21 affected members presenting bilateral lower limb weakness and muscle atrophy with neurological findings revealing a variable combination of upper and lower motor neurons defects among the individuals. Using a combined genetic approach, we identified a unique novel $\mathrm{N}$-terminal tail domain heterozygous missense mutation (lle609Thr) in the gene DYNC1H1 in all these individuals, which suggests a significant role of modifying genes in the neuronal expression pattern of $D Y N C 1 H 1$ gene mutations.

\section{Patients and methods}

\section{Data Collection}

Patients belong to a large three-generation pedigree with 21 affected individuals with ages ranging from 64 to 13 years (figure1). Patients with history of non-progressive bilateral pelvic girdle muscles weakness since childhood were considered affected. Medical records from 7 clinical centers in France (Tours, Limoges, Bordeaux, Rouen, Bayonne, Paris, Avignon) were reviewed for 18 affected individuals and electrophysiological studies were conducted in 16 of them. Peripheral blood DNA was obtained after informed consent from 20 affected and 15 non affected subjects.

\section{Next generation sequencing (NGS) based multigene panel screening}


NGS was performed on the proband (II16) using DNA extracted from whole blood. Proband's DNA sample (II16) was captured using the multigene panel for Charcot Marie Tooth diseases (NSPv.20 CMT NimbleGen, developped and validated by ARUP Lab) and sequenced with 2X100 bp paired end on an Illumina 2500 according to manufacturer's recommendation. Sequence variants were called with Genome Analysis Toolkit (v.1.6) and filtered using DbSNP, 1000 Genomes Project, 6500 Exomes and the ARUP internal database. In silico analyses of variants were performed using PolyPhen2 (http://genetics.bwh.harvard.edu/pph2/), SIFT (http://sift.jcvi.org/), and MutationTaster (http://www.mutationtaster.org/) to predict the possible disruption of protein functions.

\section{DNA Sanger sequencing}

Amplicon of DYNC1H1 exon 8 was amplified in the DNA of the 20 affected and 10 non affected individuals and sequenced using BigDye® Terminator Cycle Sequencing Kit (Applied Biosystems, Carlsbad, California) on an Applied Biosystems 3730 DNA Analyzer. Primer sequences are available upon request.

\section{Haplotype analysis}

A genome-wide scan analysis was performed among the DNAs of 15 patients, using 1,088 microsatellite markers with an average marker distance of 4cM (DeCode Genetics). Haplotype analysis at the candidate 14q32.2-q32.3 chromosomal region was performed in 20 affected individuals. Parametric computerized linkage analysis (MERLIN software) was made at the locus D14s979. For LOD score calculation, we used a model of rare autosomal dominant disease (prevalence 1.10,000), a 100\% penetrance and a 0\% phenocopy parameter. Allele frequencies at the selected locus were obtained from the online databases for Caucasian population (CEPH).

\section{Results}




\section{Various neurological phenotypes in the same family}

All the individuals examined presented childhood onset proximal weakness without deterioration of motor function over time. None of them had arthrogryposis or feet deformity at birth and all were able to walk independently at time of observation. Neurological examination and electrophysiological studies revealed remarkable differences with a variable combination of lower motor neuron disease symptoms (areflexia, distal muscle wasting, foot deformity, electrical denervation) and upper motor neuron symptoms (hyperreflexia, ankle clonus, abolished somatosensory evoked potentials). These findings are summarized in table 1. Five patients presented a pure lower motor neuron disease with a pattern of chronic denervation, corresponding to the typical SMA-LED phenotype (see patient III16 in table 2 and figure 2A). Five other patients, did not show evidence of denervation but exhibited spasticity in the lower limbs meeting the criteria of a pure hereditary spastic paraplegia (see patient II10 in table 2 and III14 in figure $2 \mathrm{~B}$ ). The other 6 patients presented an intermediate phenotype with lower and motor neuron disease symptoms (see patient III7 in table 2 and figure 2C). Mental function evaluation was not performed but most of the patients presented learning difficulties at school.

\section{Identification of a novel tail domain mutation in the gene DYNC1H1}

Next generation sequencing-based multigene panel in patient III16 allowed to identify a heterozygous variant, c.1826T>C, in the coding sequence of exon 8 of gene coding for the Heavy Chain 1 of Cytoplasmic Dynein (DYNC1H1). This variant, not previously reported in the literature or population databases, causes a missense mutation p.Ile609Thr at the protein level in a highly conserved region among vertebrate species. The mutation maps to the $\mathrm{N}$-terminal region which is the dimerization domain at the stem of $D Y N C 1 H 1$, mediating the formation of dynein heavy chain dimers and interactions with dynein intermediate light chains. Ile609Thr is predicted to be pathogenic by the computational prediction programs (SIFT, PolyPhen and MutationTaster). Whole genome sequencing in patient III16 and III3 showed the same heterozygous variant and 


\section{Genetic linkage to the DYNC1H1 gene locus on chromosome 14q32.3}

Whole genome scanning and haplotype analysis on 20 affected individuals presenting the three previously reported clinical presentations refined the locus of the disease to the same chromosomal region containing the entire sequence of gene DYNC1H1 (14q32.3, between loci D14S1066 and D14S1007), cosegregating with an autosomal dominant pattern. Linkage analysis demonstrated a positive value with a maximum LOD score at marker D14s979 (Zmax=5.30) at the recombination fraction theta $=0.00$ (data available on request).

\section{Discussion}

Spinal muscular atrophy with autosomal dominance inheritance is a clinically heterogeneous subgroup of hereditary motor neuropathies, involving multiple genes and various molecular pathways. ${ }^{24}$ Among them, Spinal Muscular Atrophy with Lower limb predominance and autosomal dominant inheritance (SMA-LED) is a lower motor neuron disease recently described, characterized by almost exclusive involvement of lower limbs, proximal predominance of muscle weakness, frequent distal muscle wasting and mild or absent progression and a typical muscle $\mathrm{MRI}$ imaging pattern with a diffuse involvement of the quadriceps and a relative sparing of the adductor compartment ${ }^{10,17}$ SMA-LED has been initially linked to mutations of gene DYNC1H1, a major component of the Dynein-Dynactin motor protein complex. The 30 reported DYNC1H1 mutations associated to the SMA-LED phenotype, ${ }^{8,9,13,14,16,17,18,19}$ are almost always located in the stem domain of the protein, while mutations located in the motor domain of DYNC1H1 are reported in malformations of cortical development (MCD) and intellectual disability ${ }^{15,22,23,25}$ without 
or with limited lower motor neuron involvement. We report in this study a novel DYNC1H1 mutation located in the stem domain, affecting both lower and upper motor neurons at various degrees, with a broad phenotypical range extending from a pure motor neuropathy to a pure spastic paraplegia. In fact, other $D Y N C 1 H 1$ tail domain mutations has already been reported in patients presenting Hereditary Spastic Paraplegia (HPN) ${ }^{14}$ and the involvement of upper motor neurons has already been evoked in SMA-LED ${ }^{17}$ or even with MCD23 patients presenting hyperreflexia of the lower limbs. In our study a same DYNC1H1 mutation is associated with either a pure motor neuron disease (SMA-LED), a pure upper motor neuron disease (HSP) or an intermediate phenotype. This suggests that the type of neuronal expression might be influenced by other factors than by the protein variant itself. These factors could be epigenetic or more probably genetic, as suggested by the clustering of pure HSP phenotypes in a same branch of the family studied here (a mother with her 3 sons). Note that this pleotropic effect of a unique DYNC1H1 tail domain mutation has been reported by Tsurusacki et al, in a family with either autosomal dominant axonal CMT or SMA-LED phenotype..$^{9}$ A similar combination of upper and lower motor neuron diseases has been reported in the phenotypical spectrum related to gene BICD2 (Bicaudal D Homolog 2) mutations ${ }^{11,12}$, a key adaptor protein interacting with DYNC1H1. BICD2 mutations are responsible for a pure autosomal dominant spinal muscular atrophy phenotype (SMA-LED2), a pure HSP and a phenotype combining lower limbs hyperreflexia and SMA-LED2. ${ }^{10,11,12}$ An increasing number of scientific data shows that Golgi functional and structural defects is a common pathophysiological feature of several lower and upper motor neuron diseases. In another hand, Dynein-Dynactin motor protein complex plays a key role in Golgi structure, dynamics and localization. Reported missense DYNC1H1 tail mutations increase BICD2-DYNC1H1 interactions, decreasing the binding of the Dynein-Dynactin motor complex to microtubules in a dominant negative manner. The subsequent impairment of cellular transport and Golgi function in DYNC1H1 related disorders plays probably a major role in motor neurons dysfunction. ${ }^{16,18,26}$ 
Figure 1. Pedigree of the 3 generations family with autosomal dominant inheritance. Filled symbols represent the affected individuals. The specific phenotypes are color coded: red symbols are used for pure Lower motor neuron phenotype (Spinal Muscular Atrophy); blue symbols for pure upper motor neuron phenotype (Spastic Paraplegia); green symbols for combined lower and upper motor neuron phenotype; black symbols for affected individuals without medical record available. 
Table 1: Clinical and electrophysiological characteristics of 16 patients of the same family. Neurogenic EMG pattern is defined by decreased or absent recruitment and large amplitude potentials. $\mathrm{ND}=$ not documented. Osteotendinous reflexes scale: $0=$ absent, $1+=$ present only with reinforcement $2+=$ normal, $3+=$ brisk, $4+=$ markedly hyperactive with clonus.

Table 2: Summary of the clinical informations from 3 patients presenting a pure upper motor neuron phenotype (III6), a pure upper motor neuron phenotype (II10) and a combined phenotype (III7) 
Figure 2. Pictures of 3 patients presenting the SMA-LED phenotype (A-III16), the HSP phenotype (B-III14) and the combined upper and lower motor neuron phenotype (C-III17). Thigh muscles wasting is more pronounced in patients III4 and III17 although pelvic girdle weakness is a common feature of all affected individuals in this family. 


\section{References}

1 Peeters K, Chamova T, Jordanova A. Clinical and genetic diversity of SMN1-negative proximal spinal muscular atrophies. Brain. 2014 Nov;137(11):2879-96.

2. Baets J, Deconinck T, De Vriendt E, Zimoń M, Yperzeele L, Van Hoorenbeeck K, et al. Genetic spectrum of hereditary neuropathies with onset in the first year of life. Brain. 2011 Sep;134(9):2664-76.

3. Fleury P, Hageman G. A dominantly inherited lower motor neuron disorder presenting at birth with associated arthrogryposis. J Neurol Neurosurg Psychiatry 1985;48:1037-48.

4. Frijns CJ, Van Deutekom J, Frants RR, Jennekens FG. Dominant congenital benign spinal muscular atrophy. Muscle Nerve 1994;17:192-7.

5. Van der Vleuten AJ, van Ravenswaaij-Arts CM, Frijns CJ, Smits AP, Hageman G, Padberg GW et al. Localisation of the gene for a dominant congenital spinal muscular atrophy predominantly affecting the lower limbs to chromosome 12q23-q24. Eur J Hum Genet 1998;6:376-82.

6. Mercuri E, Messina S, Kinali M, Cini C, Longman C, Battini R et al. Congenital form of spinal muscular atrophy predominantly affecting the lower limbs: a clinical and muscle MRI study. Neuromuscul Disord 2004;14:125-9.

7. Harms MB, Allred P, Gardner R Jr, Fernandes Filho JA, Florence J, Pestronk A, et al. Dominant spinal muscular atrophy with lower extremity predominance: linkage to 14q32. Neurology 2010;75:539-46.

8. Harms M. B, Ori-McKenney KM, Scoto M, Tuck EP, Bell S, Ma D, et al. Mutations in the tail domain of DYNC1H1 cause dominant spinal muscular atrophy. Neurology 2012 May 29;78(22):1714-20.

9. Tsurusaki Y, Saitoh S, Tomizawa K, Sudo A, Asahina N, Shiraishi H et al. A DYNC1H1 mutation causes a dominant spinal muscular atrophy with lower extremity

predominance. Neurogenetics 2012 Nov;13(4):327-32.

10. Neveling K, Martinez-Carrera LA, Hölker I, Heister A, Verrips A, Hosseini-Barkooie SM, et al. Mutations in $B I C D 2$, which encodes a golgin and important motor adaptor, cause congenital autosomaldominant spinal muscular atrophy. Am J Hum Genet. 2013 Jun 6;92(6):946-54. 
11. Oates EC, Rossor AM, Hafezparast M, Gonzalez M, Speziani F, MacArthur DG, et al. Mutations in BICD2 cause dominant congenital spinal muscular atrophy and hereditary spastic paraplegia. Am J Hum Genet 2013;92:965-73.

12. Peeters K, Litvinenko I, Asselbergh B, Almeida-Souza L, Chamova T, Geuens T, et al. Molecular Defects in the Motor Adaptor BICD2 Cause Proximal Spinal Muscular Atrophy with Autosomal-Dominant Inheritance. Am J Hum Genet. 2013 Jun 6; 92(6): 955-64.

13. Punetha J, Monges S, Franchi ME, Hoffman EP, Cirak S, Tesi-Rocha C. Exome sequencing identifies DYNC1H1 variant associated with vertebral abnormality and spinal muscular atrophy with lower extremity predominance. Pediatr Neurol 2015;52:239-44.

14. Strickland A V, Schabhüttl M, Offenbacher H, Synofzik M, Hauser NS, Brunner-Krainz M, et al. Mutation screen reveals novel variants and expands the phenotypes associated with DYNC1H1. J Neurol 2015 Sep;262(9):2124-34.

15. Fiorillo C, Moro F, Yi J, Weil S, Brisca G, Astrea G et al. Novel dynein DYNC1H1 neck and motor domain mutations link distal spinal muscular atrophy and abnormal cortical development. Hum Mutat 2014 Mar;35(3):298-302.

16. Peeters K, Bervoets S, Chamova T, Litvinenko I, De Vriendt E, Bichev S et al. Novel mutations in the DYNC1H1 tail domain refine the genetic and clinical spectrum of dyneinopathies. Hum Mutat. 2015 Mar;36(3):287-91.

17. Scoto M, Rossor AM, Harms MB, Cirak S, Calissano M, Robb S et al. Novel mutations expand the clinical spectrum of DYNC1H1-associated spinal muscular atrophy. Neurology 2015;84:668-79. 18.Niu Q, Wang X, Shi M, Jin Q.A novel DYNC1H1 mutation causing spinal muscular atrophy with lower extremity predominance. Neurol Genet. 2015 Jul 16;1(2):e20. doi:10.1212/NXG.0000000000000017. PubMed PMID: 27066557; PubMed Central PMCID: PMC4807905 
19. Ding D, Chen Z, Li K, Long Z, Ye W, Tang Z, et al. Identification of a de novo DYNC1H1 mutation via WES according to published guidelines. Sci Rep. 2016 Feb 5;6:20423. doi: 10.1038/srep20423. PubMed PMID: 26846447; PubMed Central PMCID; PMC4742772.

20. Rudnik-Schöneborn S,2, Deden F, Eggermann K, Eggermann T, Wieczorek D, Sellhaus B et al. Autosomal dominant spinal muscular atrophy with lower extremity predominance: A recognizable phenotype of BICD2 mutations. Muscle Nerve. 2016 Sep;54(3):496-500.

21. Weedon MN, Hastings R, Caswell R, Xie W, Paszkiewicz K, Antoniadi T et al. Exome sequencing identifies a DYNC1H1 mutation in a large pedigree with dominant axonal Charcot-Marie-Tooth disease. Am J Hum Genet 2011;89:308-12.

22. Willemsen MH, Vissers LE, Willemsen MA, van Bon BW, Kroes T, de Ligt J et al. Mutations in DYNC1H1 cause severe intellectual disability with neuronal migration defects. J Med Genet 2012;49:179-83.

23. Poirier K, Lebrun N, Broix L, Tian G, Saillour Y, Boscheron C et al. Mutations in TUBG1, DYNC1H1, KIF5C and KIF2A cause malformations of cortical development and microcephaly. Nat Genet 2013;45:639-47.

24 Farrar MA and Kiernan MC. The Genetics of Spinal Muscular Atrophy: Progress and Challenges. Neurotherapeutics. 2015 Apr;12(2): 290-302.

25. Hertecant J, Komara M, Nagi A, Suleiman J, Al-Gazali L, Ali BR. A novel de novo mutation in DYNC1H1 gene underlying malformation of cortical development and cataract. Meta Gene. 2016 May 18;9:124-7.

26. Martinez-Carrera LA, Wirth B. Dominant spinal muscular atrophy is caused by mutations in BICD2, an important golgin protein. Front Neurosci. 2015 Nov5;9:401. 
YUE Si - 16

842

843

844

845

846

847

848

849

850

851

852

853

854

855

856

857

858

859

860

861

862

863

864

865

866

867

868

869

870

871

872

873

874

875

876

877

878

879

880

881

882

883

884

885

886

887

888

889

890

891

892

893

894

895

896 


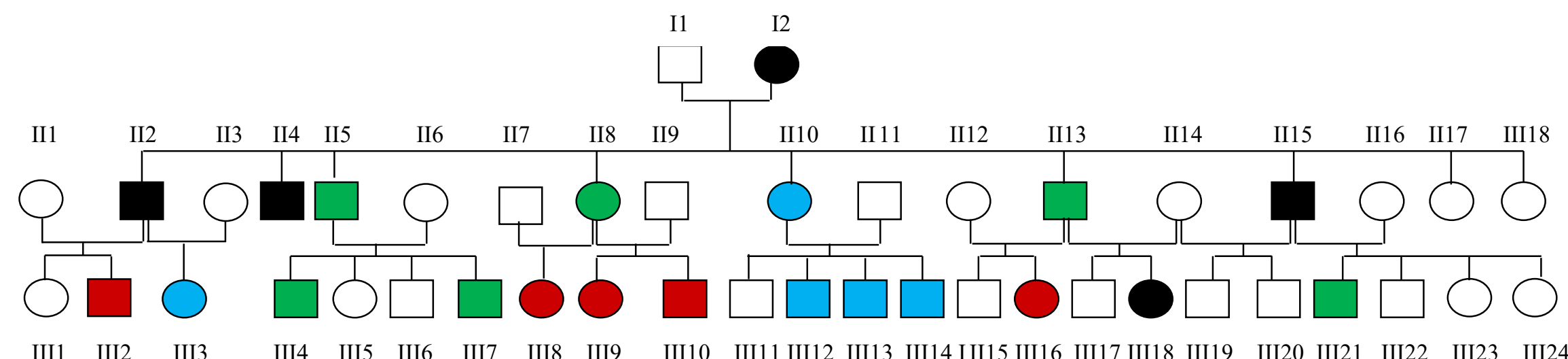


Figure 2

A. Individual III16

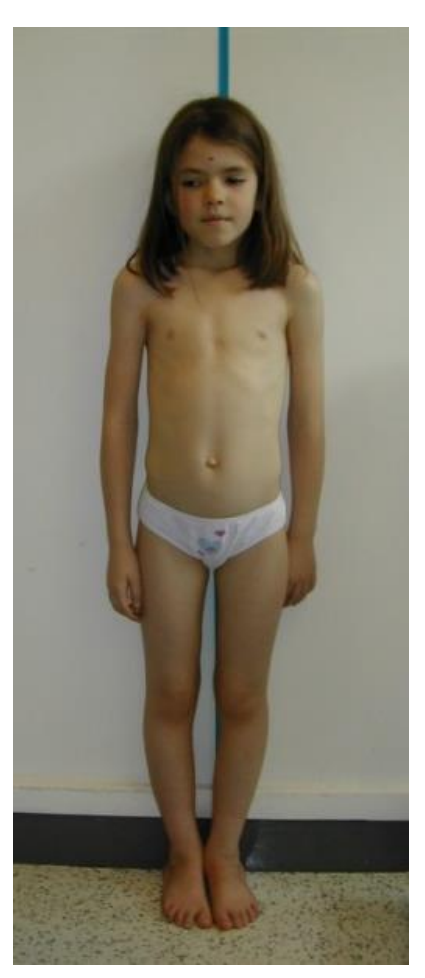

B. Individual III14
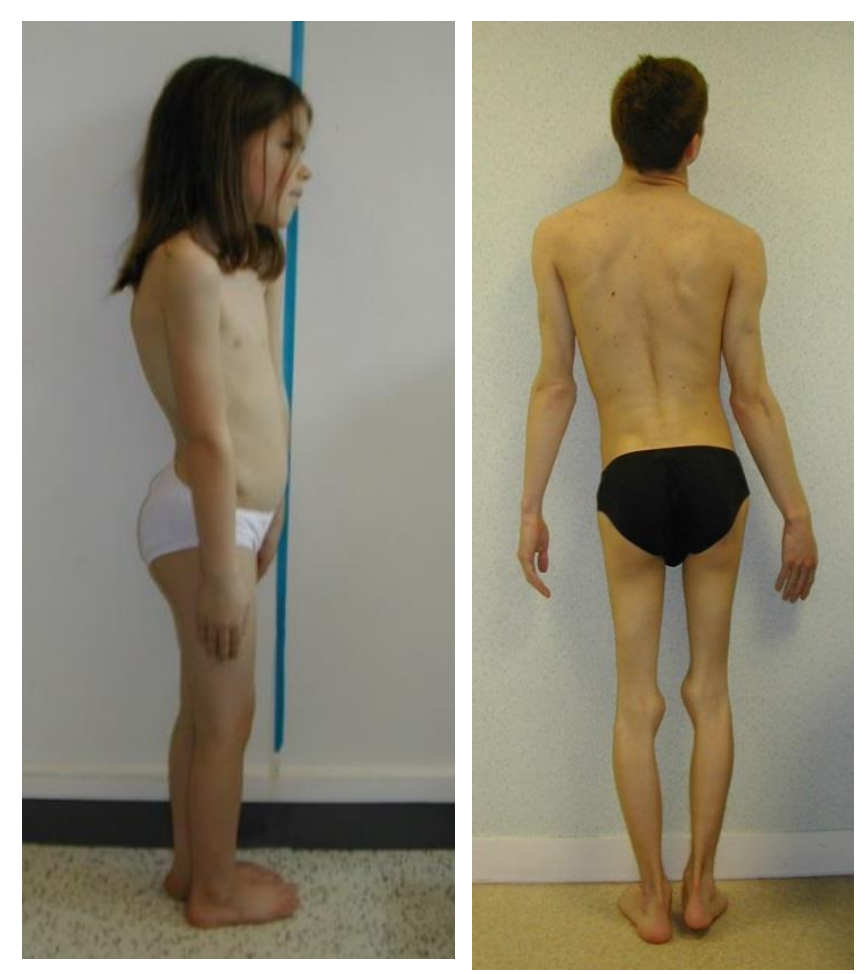

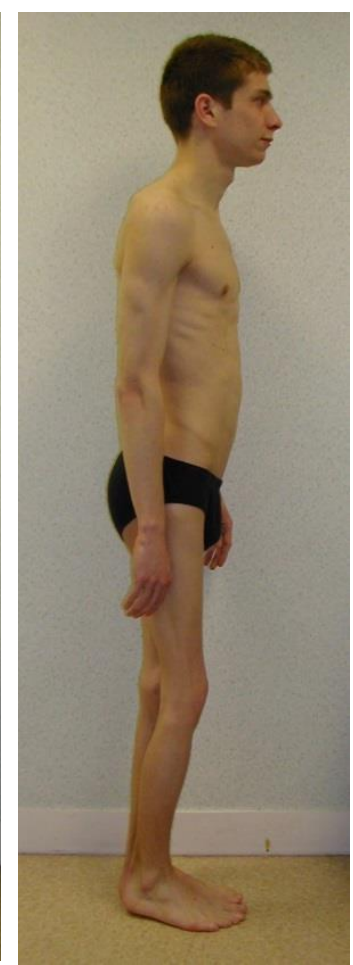

C. Individual III7

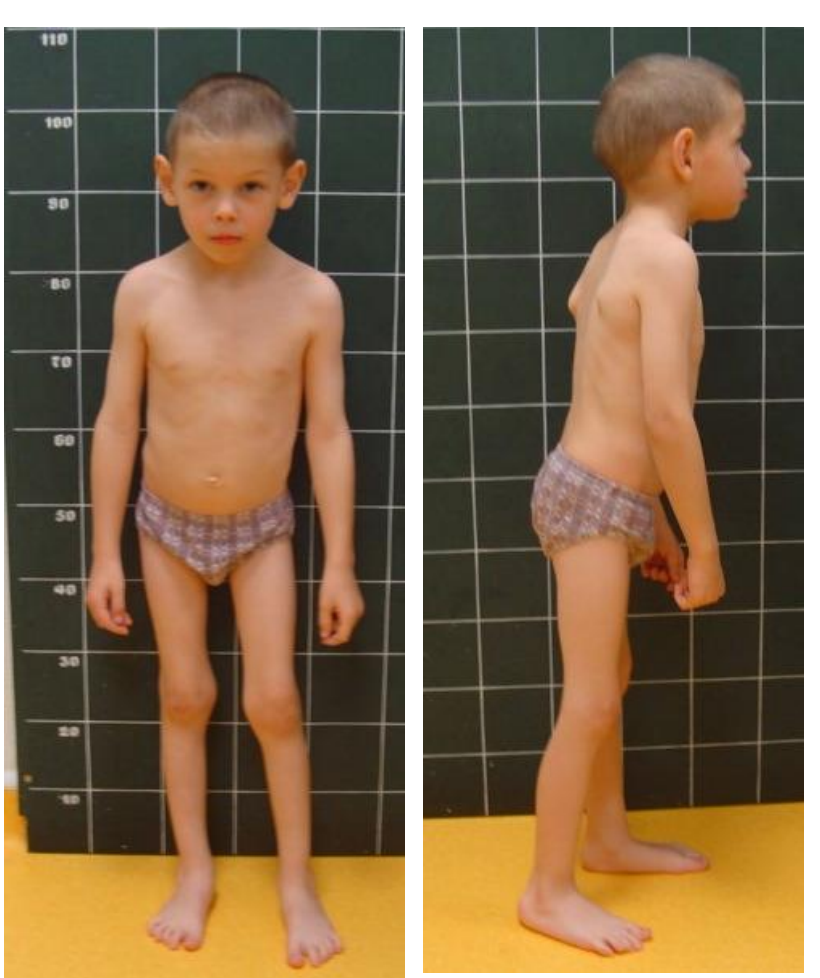




\begin{tabular}{|c|c|c|c|c|c|c|c|c|}
\hline Patients & $\begin{array}{c}\text { Age } \\
\text { at last } \\
\text { physical } \\
\text { examination }\end{array}$ & $\begin{array}{l}\text { Distribution of } \\
\text { muscle atrophy }\end{array}$ & $\begin{array}{c}\text { Feet } \\
\text { deformity }\end{array}$ & $\begin{array}{c}\text { Knee } \\
\text { reflexes }\end{array}$ & $\begin{array}{c}\text { Ankle } \\
\text { reflexes }\end{array}$ & $\begin{array}{l}\text { Age } \\
\text { at } \\
\text { EMG }\end{array}$ & $\begin{array}{c}\text { EMG Lower } \\
\text { limbs }\end{array}$ & $\begin{array}{c}\text { Lower limbs } \\
\text { motor and } \\
\text { sensory } \\
\text { NCVs }\end{array}$ \\
\hline II 5 & 42 yo & thighs & high arched & $2+$ & $4+$ & 35 уо & neurogenic & normal \\
\hline II 8 & 42 yo & legs & high arched & 0 & $3+$ & 41 yo & neurogenic & normal \\
\hline II 10 & $46 y о$ & legs and thighs & ND & $2+$ & $4+$ & $46 y o$ & normal & normal \\
\hline II 13 & 44 yo & legs & ND & ND & ND & 44 yo & normal & normal \\
\hline III 2 & 4yo & legs & flat & 0 & 0 & 4yo & neurogenic & normal \\
\hline III 3 & 4yo & ND & flat & $2+$ & $3+$ & 15 yo & normal & normal \\
\hline III 4 & 3уо & thighs and legs & flat & $2+$ & $1+$ & ND & ND & ND \\
\hline III 7 & $5 y o$ & legs and thighs & flat & $3+$ & $4+$ & $4 y o$ & neurogenic & normal \\
\hline III 8 & 17 yo & ND & high arched & $2+$ & $2+$ & 27 yo & neurogenic & normal \\
\hline III 9 & 15 yo & ND & high arched & 0 & $1+$ & 2 yo & neurogenic & normal \\
\hline III 10 & 17 yo & legs and thighs & ND & 0 & $1+$ & 3уо & neurogenic & normal \\
\hline III 12 & 19 yo & legs and thighs & flat & $3+$ & $3+$ & 14 yo & normal & normal \\
\hline III 13 & $19 y o$ & legs and thighs & flat & $3+$ & $4+$ & 14 yo & normal & normal \\
\hline III 14 & 23 уо & legs and thighs & yes & $2+$ & $4+$ & 18 yo & normal & ND \\
\hline III 16 & $5 y o$ & legs & flat & $1+$ & $1+$ & 12 yo & neurogenic & normal \\
\hline III 21 & 10 yo & ND & high arched & $1+$ & $3+$ & 10 yo & neurogenic & normal \\
\hline
\end{tabular}





\begin{tabular}{|c|c|c|c|}
\hline & Patient III16 & Patient II10 & Patient III7 \\
\hline Gender, age & Female, 8 yo & Female, 46 yo & Male, 5 yo \\
\hline Development & Normal, walked at 15 months & & $\begin{array}{l}\text { Hip dysplasia at birth. Walked at } 18 \\
\text { months with frequent falls. }\end{array}$ \\
\hline $\begin{array}{l}\text { Neurological } \\
\text { examination }\end{array}$ & $\begin{array}{l}\text { Waddling gait, frequent falls, } \\
\text { difficulties for climbing stairs } \\
\text { and long walks. Positive Gower's } \\
\text { sign. Bilateral flat feet } \\
\text { hyperlaxity of ankles. Mild leg } \\
\text { muscles atrophy. Decreased } \\
\text { knee and ankle reflexes. No } \\
\text { Babinsky, no ankle clonus. Mild } \\
\text { intention tremor of the hands. } \\
\text { No intellectual disability. }\end{array}$ & $\begin{array}{l}\text { Mild limitation of walking distance. Thighs } \\
\text { and legs muscle wasting. Brisk knee and } \\
\text { ankle reflexes with bilateral ankle clonus. } \\
\text { Normal superficial sensation at the lower } \\
\text { limbs. Decreased distal vibratory sensation } \\
\text { at the lower limbs. No upper limbs } \\
\text { weakness or atrophy. No intellectual } \\
\text { disability. }\end{array}$ & $\begin{array}{l}\text { Unable to run. Difficulties for climbing } \\
\text { stairs, rising from sitting on the floor } \\
\text { and walking on heels. Bilateral flat } \\
\text { feet, ankle valgus and Achilles tendon } \\
\text { stiffness. Buttocks, thighs and legs } \\
\text { muscle wasting. Brisk knee and ankle } \\
\text { reflexes with bilateral ankle clonus. No } \\
\text { Babinsky or Rossolimo sign. Learning } \\
\text { difficulties. }\end{array}$ \\
\hline Electrophysiological studies & $\begin{array}{l}\text { Lower limbs electromyography } \\
\text { and conduction studies showed } \\
\text { decreased or absent } \\
\text { recruitment with large } \\
\text { amplitude potentials. Normal } \\
\text { motor and sensory nerve } \\
\text { conduction velocities No } \\
\text { spontaneous fibrillation } \\
\text { recorded }\end{array}$ & $\begin{array}{l}\text { Normal lower limbs electromyography and } \\
\text { conduction studies } \\
\text { Somatosensory evoked potentials } \\
\text { abolished (provoked by lower limbs nerves } \\
\text { stimulation) }\end{array}$ & $\begin{array}{l}\text { Lower limbs electromyography and } \\
\text { conduction studies showed decreased } \\
\text { or absent recruitment with large } \\
\text { amplitude potentials. Normal motor } \\
\text { and sensory nerve conduction } \\
\text { velocities }\end{array}$ \\
\hline Imaging & ND & Brain and Spine MRI normal & ND \\
\hline
\end{tabular}

